\title{
Estimation of Carbon Sequestration in Tropical Peat Swamp Forest in Central Kalimantan Using Satellite Based on Primary Productivity
}

\author{
Dewa Ayu Mery Agustin a*, Takahiro Osawa b,c, I Putu Gede Ardhana a \\ a Graduate Study of Environmental Sciences, Udayana University, Denpasar, Bali 80232, Indonesia \\ ${ }^{b}$ Graduate School of Science and Engineering, Yamaguchi University, Ube Shi Tokiwadai 2-16-1, 7550092, Japan \\ c Center for Remote Sensing and Ocean Sciences (CReSOS), Udayana University, PB Sudirman Street, Denpasar, \\ Bali 80232, Indonesia \\ * Correspondence: mery_sponge07@yahoo.com
}

Received: 27 Desember 2017; Accepted: 30 November 2018; Available online: 1 Desember 2018

\begin{abstract}
One of approach that can be used to estimate the carbon sequestration by vegetation is to calculate the Gross Primary Productivity (GPP) in Central Kalimantan. GPP is total carbon that can be absorbed by vegetation to be used in the process of photosynthesis. The purpose of this study is to estimate the value of GPP using Vegetation Photosynthesis and Respiration Model (VPRM) and analyze the data comparison between GPP value data derived from flux tower and GPP value data from MODIS data. The field data from flux tower was taken by Hirano et al. (2007) from January 1, 2004 to December 31, 2005. The MODIS data is used MODIS Surface Reflectance Level 3 data year 2004 to 2005. According to the result of this study, the maximum GPP value year 2004 and 2005 showed $302.365 \mathrm{gC} \mathrm{m}-2$ per month (February 2004) and $366.841 \mathrm{gC} \mathrm{m}-2$ per month (June 2005). The minimum GPP value year 2004 and 2005 was $166.003 \mathrm{gC} \mathrm{m}-2$ per month (November 2004) and $187.663 \mathrm{gC} \mathrm{m}-2$ per month (March 2005). The total value of GPP in year 2004 was $1,134.231 \mathrm{gC} \mathrm{m-}$ $2 \mathrm{yr}-1$ and in year 2005 the value was $1,109.001 \mathrm{gC} \mathrm{m}-2 \mathrm{yr}-1$. The correlation coefficient between GPP value from flux tower and GPP value from MODIS - VPRM showed in dry season, $r=0.766$ and in rainy season, $r=0,839$.
\end{abstract}

Keywords: moderate-resolution imaging spectroradiometer (MODIS); gross primary productivity (GPP); carbon sequestration; vegetation photosynthesis and respiration model (VPRM)

\section{Introduction}

Peatlands store at least 550 gigatons of carbon in the organic soil layer, or about double the amount of carbon stored in forests around the world. Indonesia currently has the largest tropical peat forests in the world with 22 million acres spread across Kalimantan, Papua, which has a third of peatlands in Indonesia and Sumatra (Jaenicke et al., 2008). Like tropical rain forest, tropical peat swamp forests in Indonesia are also being threatened. The threats are in the form of illegal logging, burning, and land conversion to agriculture and oil palm plantations, as well as fires caused by drought. Currently, 10 million hectares of peatland forests in Sumatra and Kalimantan are found degraded. Less than $4 \%$ is covered by forest and only $11 \%$ of the forests are well covered (Osaki et al., 2016).

One of the largest peat swamp forest in Indonesia is in Sebangau National Park which lies between Kahayan and Sebangau River, Central Kalimantan (Morrogh-Bernard et al., 2003). According to WWF-Indonesia Program Manager Central Kalimantan Rosenda Ch. Kasih, rampant illegal logging and forest fires causing conditions in Sebangau concern with the loss of a number of plant species, threatened peatlands and the existence of orangutans and other animals (WWF Indonesia, 2014). 
One of the project to reduce carbon emissions is REDD. REDD is a project to reduce greenhouse gas emissions by compensate those who did avoided deforestation and forest degradation. Deforestation or emissions reductions are recorded as credits that can be sold on the carbon market. Emitters of greenhouse gases will pay compensation as the amount of emissions produced to developing countries that still has large forests area such as Indonesia and will be used as a fund for the rehabilitation of degraded forests. Therefore, the ability of forests to absorb carbon need to be considered.

Along with the development of remote sensing technology, many methods or model for estimating carbon sequestration developed. Most of the methods or model use the Gross Primary Productivity (GPP) approach (e.g. As-syakur et al., 2010). GPP is the total carbon that can be absorbed by plants at any given time (Wang et al., 2012). GPP calculation with remote sensing models basically use Light Use Efficiency (LUE) with the vegetation index NDVI (Normalized Difference Vegetation Index) (Sims et al., 2006; Yuan et al., 2014). In this research, we will use VPRM to calculate GPP in tropical peat swamp forest. Therefore, we need to do a research about carbon sequestration in tropical peat swamp forest Central Kalimantan using gross primary productivity approach and remote sensing satellite data to get the information about GPP in tropical peat swamp forest vegetation.

\subsection{Study Area}

The research is located in the part of tropical peat swamp forests in Central Kalimantan province, more precisely in Sebangau National Park, Kalampangan, Palangkaraya (Figure 1). Geographically, Kalampangan, Central Kalimantan, situated on the equator between $02^{\circ} 20^{\circ} 42^{\prime \prime} \mathrm{S}, 144^{\circ} 02^{\circ} 11^{\prime \prime} \mathrm{E}$. Central Kalimantan is one of three provinces that have a flux tower in Indonesia to directly measure the condition of the forest such as the carbon sequestration.

The specific research location is adapted to the field data (Palangkaraya flux tower data) which took place on the former Mega Rice Project area Block C. The flux tower data are available in Asiaflux Network (Hirano et al., 2007). Data collection was conducted in October - November 2013. The data was from January 1, 2004 until 31 Dec 2005 tower data.

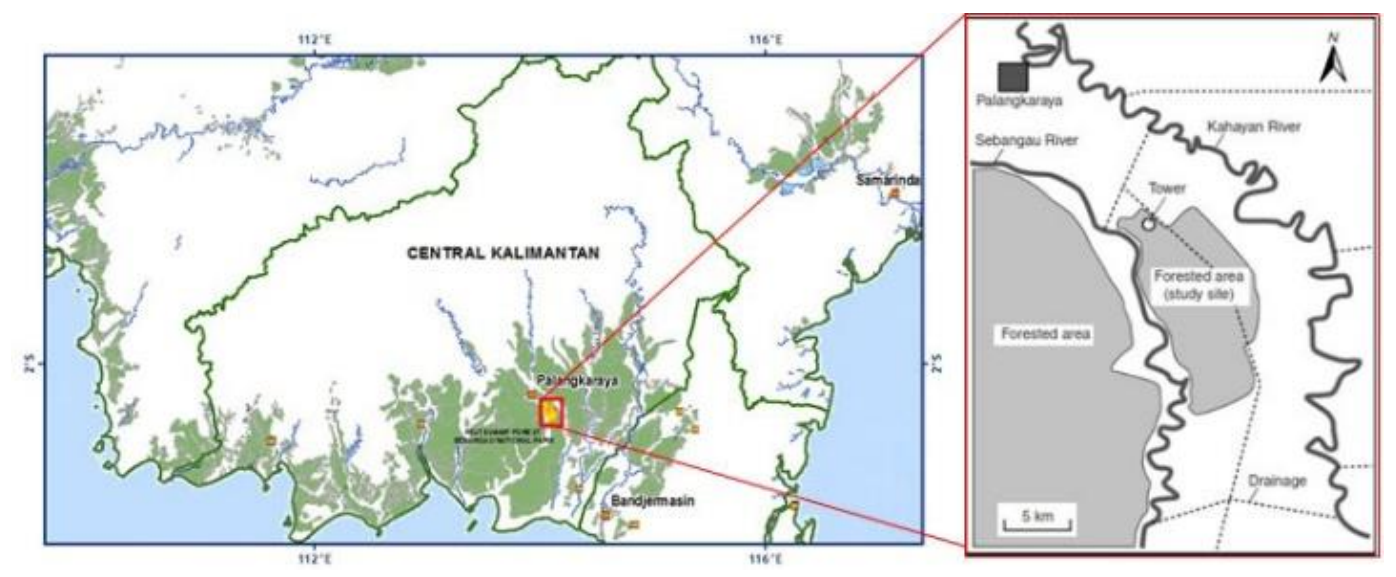

Figure 1. Research area (source: Hirano et al. 2007)

\subsection{Research Materials and Instruments}

The materials used for this research are the hourly Flux tower data year 2004 and 2005 and also the 8-days MODIS TERRA-Surface Reflectance L3 500m year 2004 and 2005. The research instruments are mostly used for processing satellite data are ENVI 4.8 to processing the MODIS data, ArcGIS 10 for mapping the results of MODIS satellite data processing, Microsoft Excel 2013 and SPSS 17 for statistical analysis. 


\subsection{Research Prosedure and Data Analysis}

This study is processing the MODIS satellite data to obtain information about the amount of carbon sequestered through GPP methods in tropical peat swamp forest in Central Kalimantan.

\section{Cropping}

Cropping is used to limit the research area. Cropping process was done by software ENVI 4.8.

\section{Geometric Correction}

To correct geometric distortion that occurs during the process of data collecting due to the curvature of the earth's surface, the satellite movement, and instrument errors.

3. Radiometric Correction

Radiometric correction needs to be done so that the information in the image data can clearly be read and interpreted.

4. EVI Analysis

In the calculation, EVI adjusts the reflectance in the red band as a function of the reflectance in the blue band (pblue). From equation (2), we put the value of $\mathrm{G}=2.5, \mathrm{C} 1=$ $6, \mathrm{C} 2=7.5$, and $\mathrm{L}=1$, then we get the complete equation of EVI.

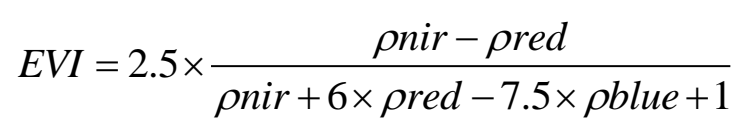

\section{GPP Calculation Using VPRM}

There are 3 main parameter those are used to calculate the GPP. They are the vegetation, light, and also some environment matters.

a. The vegetation is represented by $F_{A P A R_{P A V}}$. From recent studies by Xiao et al. (2004), FAPAR $_{\text {PAV }}$ is the linear function of EVI with the value of coefficient $a$ is set to be 1.0. The formula of FAPAR PAV $_{\text {is }}$ shown below:

$$
\begin{gathered}
F A P A R_{P A V}=a \times E V I \\
F A P A R_{P A V}=E V I
\end{gathered}
$$

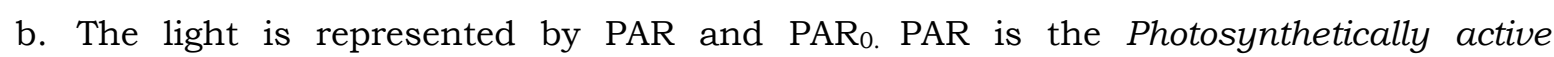
radiation which are the total energy/light that can be absorbed by the vegetation (FAPAR $\left.{ }_{\mathrm{PAV}}\right) . P A R_{0}$ is the adjustable parameters for description of the light-dependent part of Net Ecosystem Exchange (NEE). These value is derived from tower flux data.

c. The environment matters those are affect the GPP are temperature, water/soil, and leaf age. These parameters affect the light use efficiency $(\varepsilon)$. The equation of $\varepsilon$ is shown at equation (3) below:

$$
\varepsilon=\lambda \times T_{\text {scalar }} \times W_{\text {scalar }} \times P_{\text {scalar }}
$$

Where $\lambda$ is the maximum light use efficiency ( $\mu \mathrm{mol} \mathrm{CO} 2 / \mu \mathrm{mol}$ PAR). Tscalar, Wscalar, Pscalar are the the downward-regulation scalars for the effects of temperature, water, and leaf phenology on light use efficiency of forests. Pscalar in evergreen forest, according to the previous research by Xiao et al. (2004), the value is 1 the whole year. The full equation for GPP with VPRM model (Xiao et al., 2004) is:

$$
\begin{gathered}
G P P=\varepsilon \times F A P A R_{P A V} \times \frac{1}{1+\frac{P A R}{P A R_{0}}} \times P A R \\
G P P=\left(\lambda \times T_{\text {scalar }} \times W_{\text {scalar }} \times P_{\text {scalar }}\right) \times E V I \times \frac{1}{1+\frac{P A R}{P A R_{0}}} \times P A R
\end{gathered}
$$




\section{Results and Discussion}

Estimating carbon sequestration is very important considering the vegetation especially peatswamp forest is one of the carbon absorber that can be minimize the carbon emissions in the form of carbon dioxide as one of the greenhouse gases that cause global warming. By knowing the amount of carbon dioxide that can be absorbed by vegetation, the conservation efforts to reduce global warming and also for carbon trading could be improved.

\subsection{GPP - Flux Tower Data}

The data was derived from Palangkaraya flux tower and was available in Asiaflux Network. The data was an hourly data, but this study only used data at the specific time when MODIS satellite data arrived and record the research area which was every 8-days data at 10.00 o'clock local time. Then the 8-days data was calculated into monthly data and also annual data so the data can be compared with GPP MODIS-VPRM data.

The total value of GPP observed in Palangkaraya flux tower in 2004 was 2,929.492 gC $\mathrm{m}^{-2} \mathrm{yr}^{-1}$.With the number area of $20,824.378 \mathrm{ha}$, the total annual GPP value observed in this flux tower in 2004 were $610,048.608 \mathrm{tC} \mathrm{yr}^{-1}$. The total value of GPP in 2005 was $3,095.524 \mathrm{gC} \mathrm{m}^{-2} \mathrm{yr}^{-1}$. With the number area of $20,824.378 \mathrm{ha}$, the total annual GPP

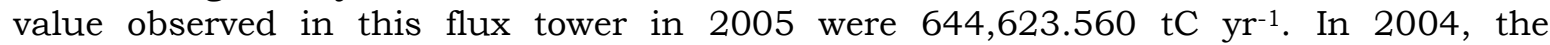
maximum value was $302.37 \mathrm{gCm}^{-2} /$ month and the minimum value was $166.003 \mathrm{gCm}^{-2}$ /month. In 2005, the maximum value was $366.84 \mathrm{gCm}^{-2} /$ month and the minimum value was $187.66 \mathrm{gCm}^{-2} /$ month (Table 1 ).

Table 1. Mean Value of GPP Flux Tower per Month

\begin{tabular}{ccc}
\hline Month & $\begin{array}{c}\text { GPP value year 2004 } \\
\left.(\mathrm{gC} \mathrm{m})^{-2} \text { per month }\right)\end{array}$ & $\begin{array}{c}\text { GPP value year 2005 } \\
\left(\mathrm{gC} \mathrm{m}^{-2} \text { per month }\right)\end{array}$ \\
\hline January & 276.648 & 307.782 \\
February & 302.365 & 301.495 \\
March & 280.150 & 187.663 \\
April & 226.729 & 278.779 \\
May & 166.003 & 189.264 \\
June & 250.602 & 232.602 \\
July & 258.866 & 224.772 \\
August & 241.247 & 280.332 \\
September & 267.260 & 366.841 \\
October & 230.223 & 247.115 \\
November & 210.027 & 233.707 \\
December & 219.372 & 245.172 \\
\hline
\end{tabular}

\subsection{GPP MODIS - VPRM}

The GPP value in the tropical peatswamp forest in Sebangau National Park, Central Kalimantan province was estimated using MODIS Terra data and also Vegetation Photosynthesis and Respiration Model approach. The data was available at http://www.earthexplorer.com. The total value of GPP estimated from MODIS data using the VPRM model in 2004 was $1,134.231 \mathrm{gC} \mathrm{m}^{-2} \mathrm{yr}^{-1}$. With the number area of 20,824.378 ha, the annual GPP value derived from this flux tower in 2004 were $236,196.588 \mathrm{tC}^{-1}$. Meanwhile, the total value of GPP MODIS-VPRM in 2005 was $1,109.001 \mathrm{gC} \mathrm{m}^{-2} \mathrm{yr}^{-1}$. With the number area of $20,824.378$ ha, the annual GPP value derived from this flux tower in

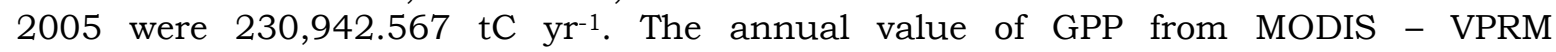
distribution map is shown in Figure 2. 
Year 2004

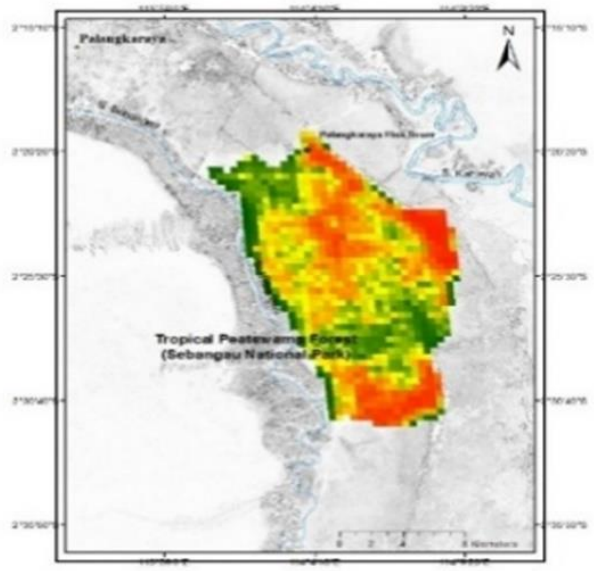

Year 2005

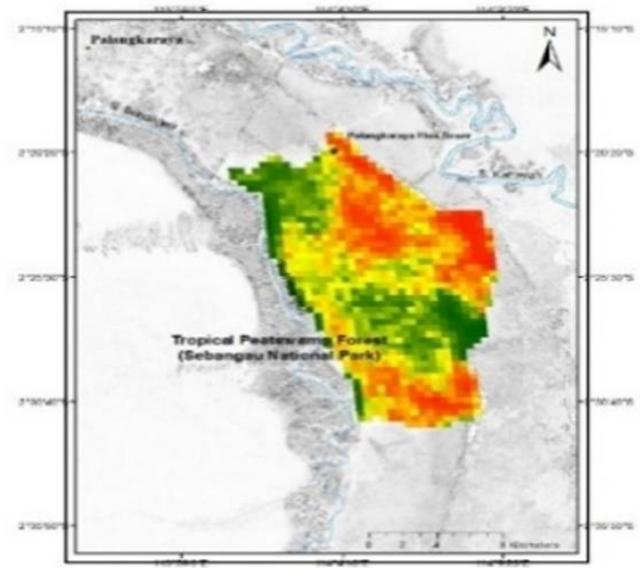

295.7

( $\left.\mathrm{gCm}^{-2} / \mathrm{month}\right)$

Figure 2. Annual value of GPP MODIS - VPRM distribution

Table 2. Mean Value of GPP MODIS - VPRM per Month

\begin{tabular}{ccc}
\hline Month & $\begin{array}{c}\text { GPP value year 2004 } \\
\left(\mathrm{gC} \mathrm{m}^{-2} \text { per month }\right)\end{array}$ & $\begin{array}{c}\text { GPP value year 2005 } \\
\left(\mathrm{gC} \mathrm{m} \mathrm{m}^{-2} \text { per month }\right)\end{array}$ \\
\hline January & 90.080 & 88.254 \\
February & 100.471 & 105.519 \\
March & 101.763 & 59.083 \\
April & 94.470 & 98.849 \\
May & 102.490 & 70.936 \\
June & 116.139 & 102.328 \\
July & 116.354 & 97.445 \\
August & 108.559 & 103.400 \\
September & 107.704 & 144.196 \\
October & 60.697 & 79.023 \\
November & 71.119 & 74.453 \\
December & 64.383 & 85.514 \\
\hline
\end{tabular}

Although there are some differences in the value of GPP which in the dry season is greater than the rainy season but the average value of GPP throughout the year was stable in which the change in value between 2004 and 2005 was not significant. In the year of 2004 and 2005, the total value of GPP which is derived from MODIS data with VPRM calculation ranged between $1,134.231$ and $1,109.001 \mathrm{gC} \mathrm{m}^{-2}$ per year. This is influenced by the tropical climate in Indonesia, even Central Kalimantan is right passed the equator. In tropical climates, both in the dry season and the rainy season, the region can still receive radiation of sunlight throughout the year despite the rainy season, the light intensity of the sun tend to be smaller than in the dry season. The clouds also occurs thicker and the rainfall occurs more. As a result of the stability of sunlight irradiation throughout the year, the vegetation can photosynthesize longer. This leads to increased primary productivity GPP. In 2004, the maximum value was $116.354 \mathrm{gCm}^{-}$ $2 /$ month and the minimum value was $60.697 \mathrm{gCm}^{-2} /$ month. In 2005 , the maximum value was $144.196 \mathrm{gC} \mathrm{m}^{-2} /$ month and the minimum value was $59.083 \mathrm{gCm}^{-2} /$ month (Table 2). 
The distribution maps of GPP seasonal value from MODIS satellite using VPRM in peatswamp forest Central Kalimantan in 2004 is shown in Figure 3 and Figure 4. The distribution maps of GPP seasonal value from MODIS satellite using VPRM in peatswamp forest Central Kalimantan in 2005 is shown in Figure 5 and Figure 6.

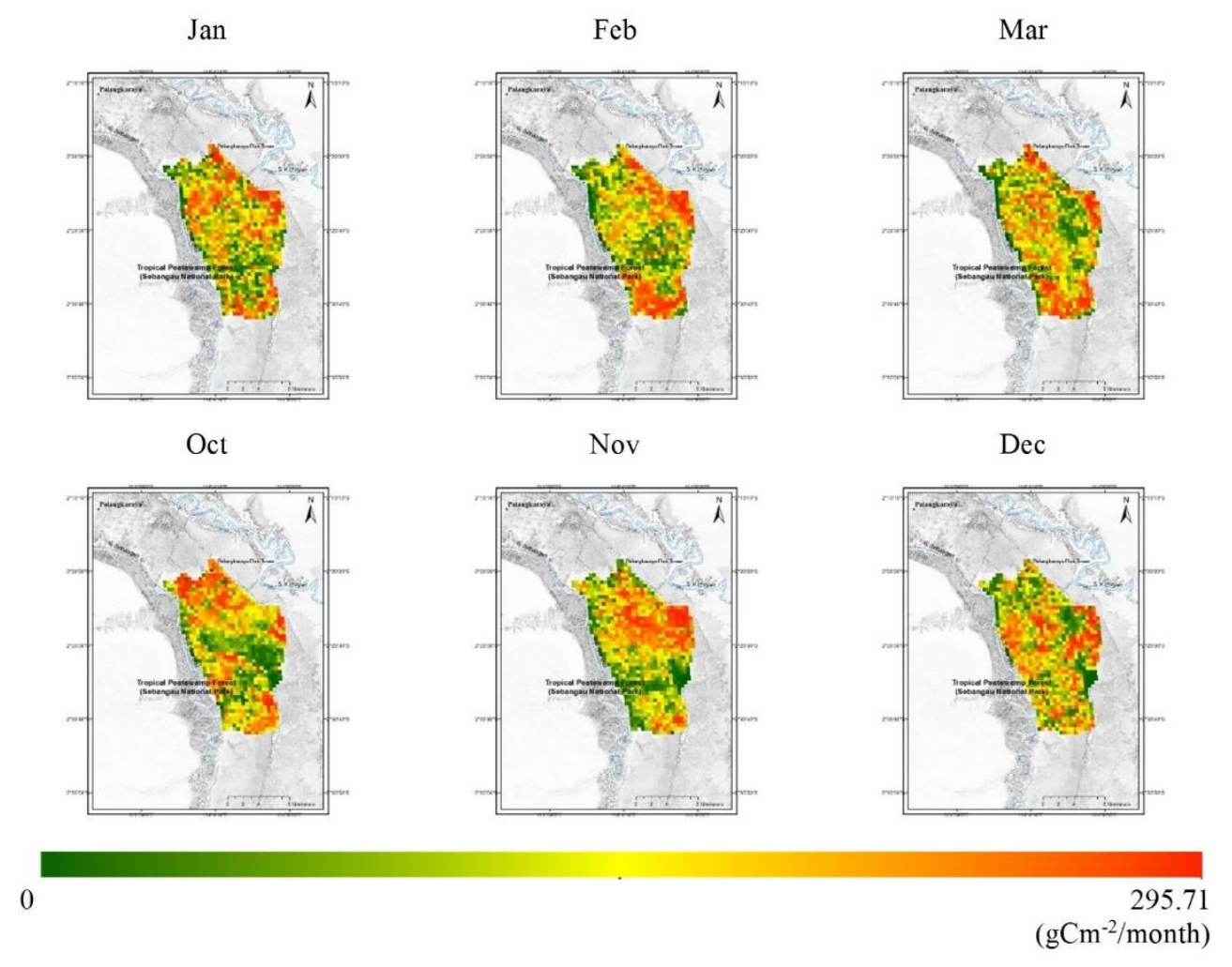

Figure 3. Map distribution of GPP value from MOFIS - VPRM in Rainy season year 2004

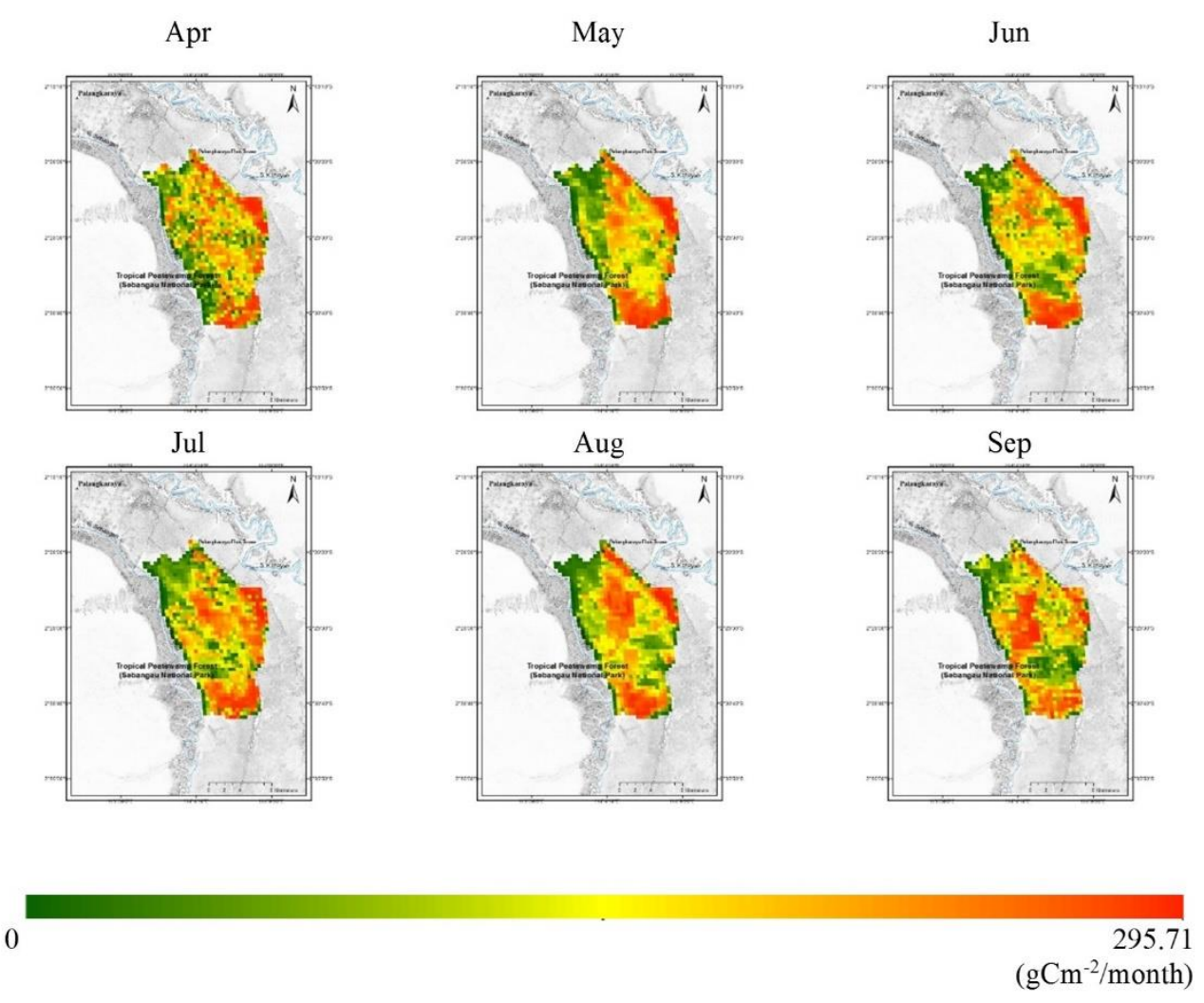

Figure 4. Map distribution of GPP value from MODIS -VPRM in dry season year 2004 
Jan

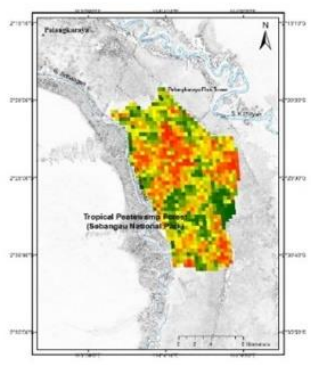

Oct

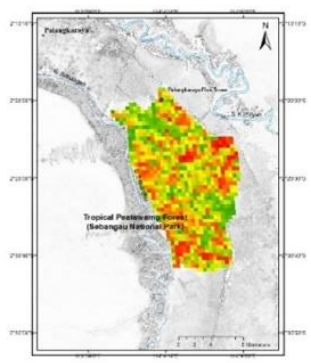

Feb

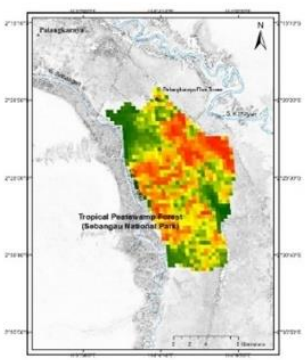

Nov

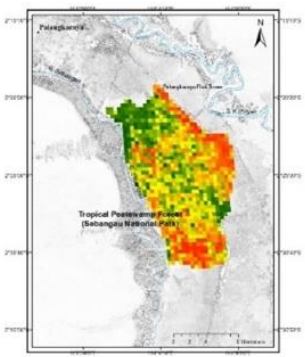

Mar

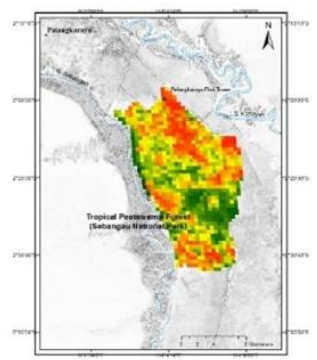

Dec

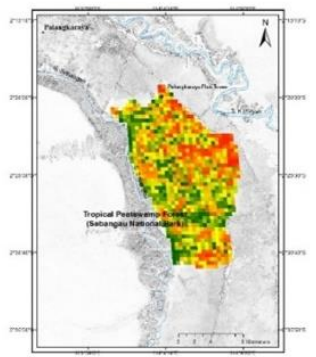

$\left(\mathrm{gCm}^{-2} / \mathrm{month}\right)$

Figure 5. Map distribution of GPP value from MODIS - VPRM in rainy season year 2005

Apr

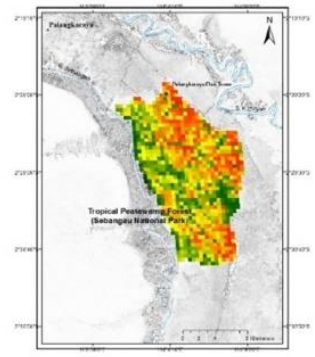

Jul

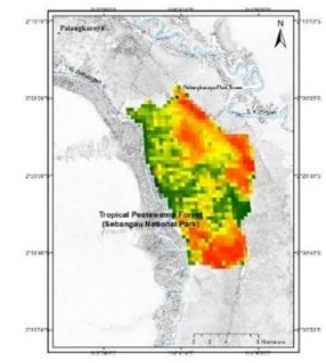

May

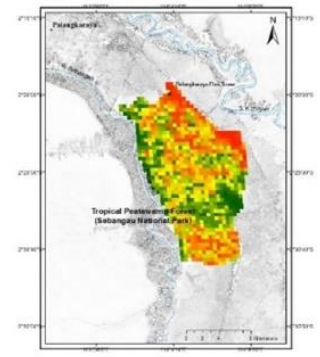

Aug

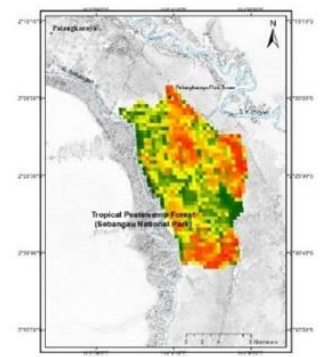

Jun

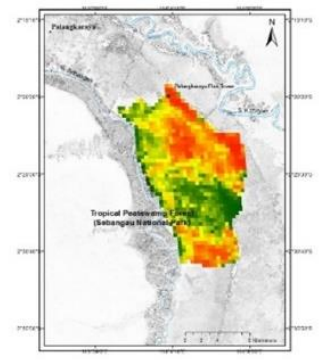

Sep

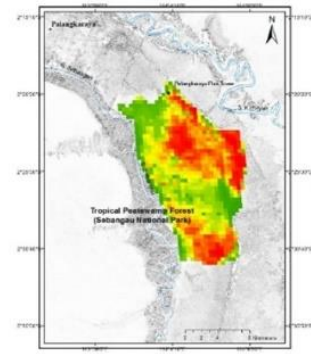

295.7

$\left(\mathrm{gCm}^{-2} / \mathrm{month}\right)$

Figure 6. Map distribution of GPP value from MODIS- VPRM in dry season year 2005

Indonesia is the country with tropical climate and has two season. Dry season occurs from April to September and rainy season occurs from October to March. From those result, it showed that the maximum value of GPP both in year 2004 and 2005 appeared in dry season and the minimum value of GPP appeared in rainy season. It happened because the solar radiation appears higher than in rainy season. This leads to the large number of solar energy that can be absorbed by vegetation so that the process of 
photosynthesis is more optimal in the dry season. While in rainy season, there are lots of thick clouds, especially in the middle until the end of year 2005. This was inhibit solar radiation to reach the ground, so that the rainy season, although the plant is still photosynthesize but photosynthetic rate is lower than in the dry season.

The level of vegetation greenness is one parameter that is affecting that value of GPP. The higher the value of greenness level indicate the more the amount of chlorophyll contained in vegetations and also the more dense the vegetation. A large amount of chlorophyll indicates that the vegetation is healthy and more carbon in the form of carbon dioxide which is one of the major greenhouse gases can be absorbed by the vegetation. In remote sensing, the vegetation greenness level is expressed in the form of vegetation index.

In this study, the vegetation index used is EVI. The EVI value from MODIS imagery at this site in 2005 ranged between $0.571-0.854$ and the average value was 0.708 . The value reached its peak during the early rainy season. However, in 2004, the EVI value ranged between $0.537-0.941$ and the average value was 0.692 . The maximum value occurred during dry season and the minimum value occurred in rainy season. Peatswamp forests also tends to get very dry during this season and it might get burned. It might happened because in dry season, although the rainfall is not often appears, but the sunlight appears much hotter and brighter so the vegetation get the solar radiation more and the vegetation produce the chlorophyll more. That is why during year 2004 in dry season, like the EVI value that reached the maximum value, the GPP value also reached its maximum value. In rainy season, the Sebangau National Park tropical peatswamp forest was cloudy. Because so many cloud appeared, they blocked the sunrays and the solar radiation so the vegetation could not get the solar energy (PAR) much.

\subsection{Relationshio between GPP Flux Tower and GPP MODIS - VPRM}

Overall, the values of GPP MODIS-VPRM were smaller than GPP from flux tower measurement. However, in dry season year 2004 from April to September, the values of GPP MODIS - VPRM were overestimate or bigger than the GPP from flux tower. The distribution value of GPP from flux tower measurement and GPP MODIS - VPRM is shown in Figure 7.

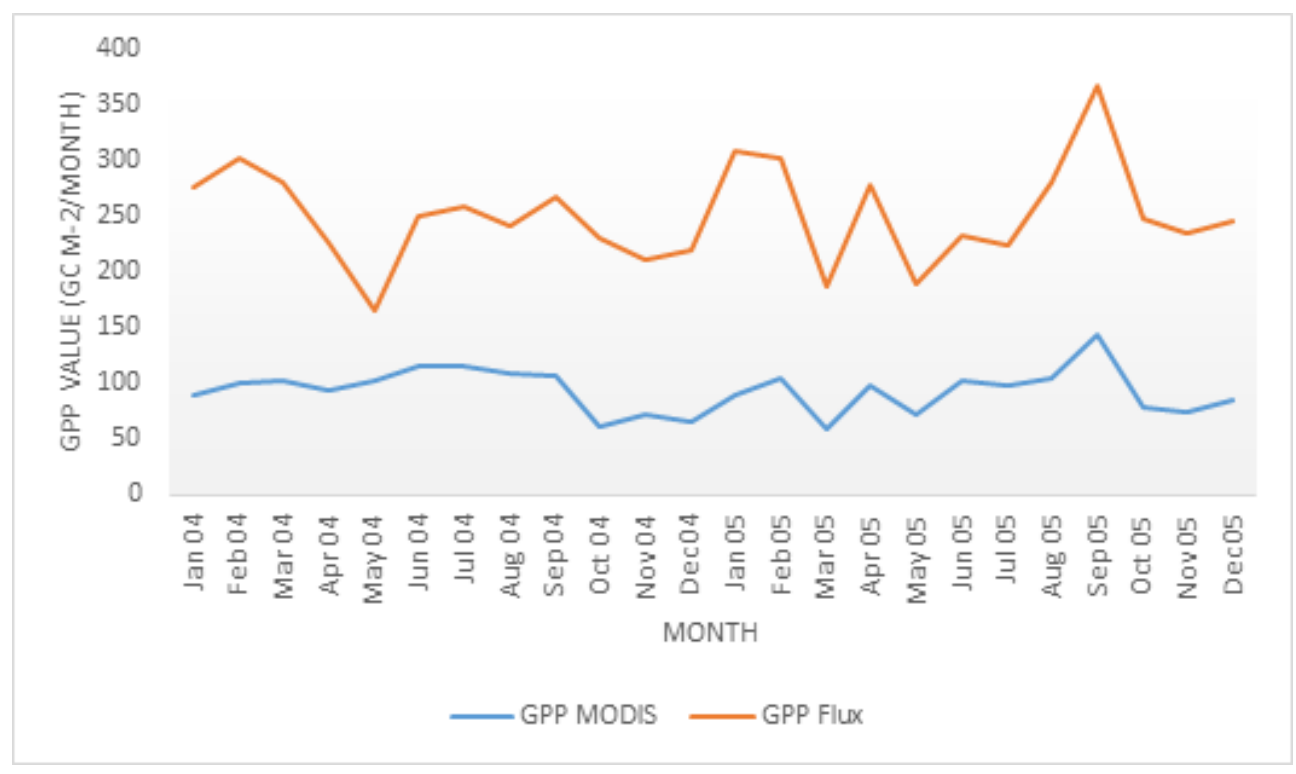

Figure 7. Distribution value of GPP flux tower and GPP MODIS - VPRM

The correlation between the GPP observation data with flux tower in Palangkaraya and GPP MODIS-VPRM was relative small. The correlation was a linear regression with the coefficient of determination $\left(\mathrm{R}^{2}\right)$ was 0.622 . The equation was $\mathrm{y}=1.3692 \mathrm{x}+123.06$ (Figure 8). 


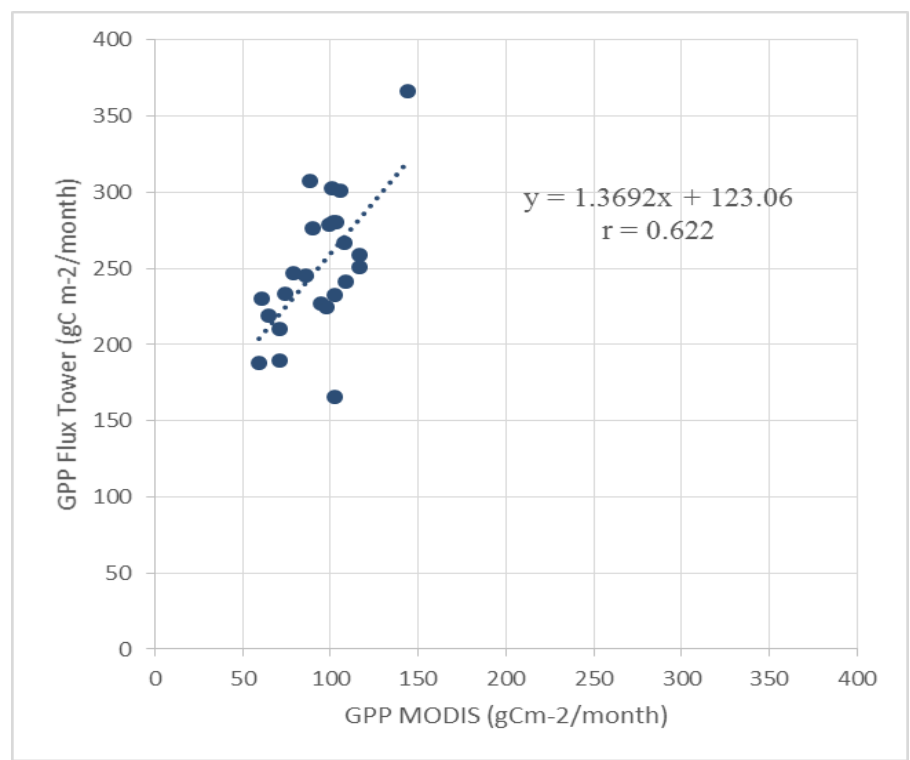

Figure 8. The relationship between GPP flux tower data and PP MODIS - VPRM data year 2004 and 2005

Dry Season in Indonesia occurs from April until September. In dry season, the correlation between the field data from flux tower in Palangkaraya and MODIS - VPRM data was a linear regression. The correlation value $(\mathrm{r})$ was 0.766 . The equation was $\mathrm{y}=$ $2.2699 x+9.7202$ (Figure 9).

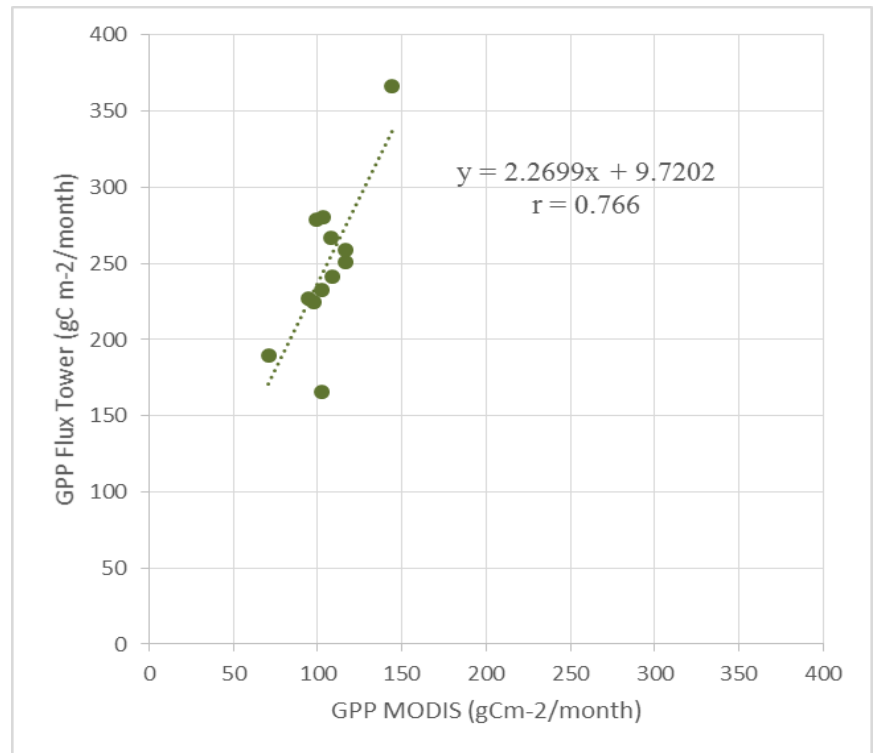

Figure 9. The relationship between GPP flux tower data and GPP MODIS - VPrM data in dry season 2004 and 2005

Rainy Season in Indonesia occurs from October until March. In rainy season, the correlation between the field data from flux tower in Palangkaraya and MODIS - VPRM data was a linear regression. The correlation value $(r)$ was 0.893 . The equation was $y=$ 2.1929x + 74.327 (Figure 10). 


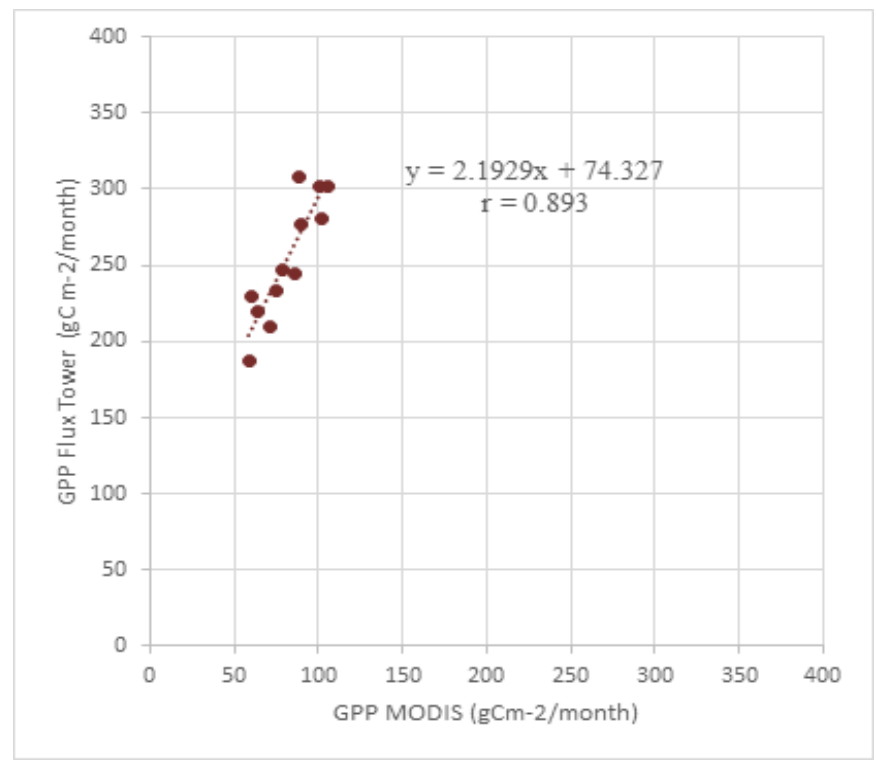

\section{Conclusion and Suggestion}

\section{1 Conclousion}

The total annual GPP MODIS- VPRM estimation in both year 2004 and 2005 were $236,196.588 \mathrm{tC} \mathrm{yr}-1$ and 230,942.567 tC yr-1 with the average value were $94.519 \mathrm{gC} \mathrm{m}-2$ yr-1 and $92.417 \mathrm{gC} \mathrm{m}-2 \mathrm{yr}-1$. The carbon sequestration during dry season in both year 2004 and 2005 appeared higher than GPP value that appeared during the rainy season. The value of GPP MODIS - VPRM was smaller than GPP flux tower. The estimation the value of GPP with remote sensing method using MODIS imagery can be done in the tropical peatswamp forest area like in Sebangau National Park because the relationship between GPP flux tower and GPP MODIS-VPRM is high with $r=0.839$ in rainy season and $r=0.766$ in dry season.

\subsection{Suggestion}

1. To provide good analyses it is need many samples in different location to get the better correlation and a new accurate equation.

2. Use different model and also different vegetation index to estimate GPP in order to get better comparison.

3. The further study need to be done to analyze the different value between GPP flux tower and GPP estimation with remote sensing model.

\section{References}

As-syakur, A. R., Osawa, T., \& Adnyana, I. W. S. (2010). Medium spatial resolution satellite imagery to estimate gross primary production in an urban area. Remote Sensing, 2(6), 1496-1507.

Hirano, T., Segah, H., Harada, T., Limin, S., June, T., Hirata, R., \& Osaki, M. (2007). Carbon dioxide balance of a tropical peat swamp forest in Kalimantan, Indonesia. Global Change Biology, 13(2), 412-425.

Jaenicke, J., Rieley, J. O., Mott, C., Kimman, P., \& Siegert, F. (2008). Determination of the amount of carbon stored in Indonesian peatlands. Geoderma, 147(3-4), 151-158.

Morrogh-Bernard, H., Husson, S., Page, S. E., \& Rieley, J. O. (2003). Population status of the Bornean orang-utan (Pongo pygmaeus) in the Sebangau peat swamp forest, Central Kalimantan, Indonesia. Biological Conservation, 110(1), 141-152.

Osaki, M., Nursyamsi, D., Noor, M., \& Segah, H. (2016). Peatland in Indonesia. In Tropical Peatland Ecosystems (pp. 49-58). Springer, Tokyo.

Sims, D. A., Luo, H., Hastings, S., Oechel, W. C., Rahman, A. F., \& Gamon, J. A. (2006). Parallel adjustments in vegetation greenness and ecosystem $\mathrm{CO} 2$ exchange in response to drought in a Southern California chaparral ecosystem. Remote Sensing of Environment, 103(3), 289-303. 
Wang, X., Ma, M., Huang, G., Veroustraete, F., Zhang, Z., Song, Y., \& Tan, J. (2012). Vegetation primary production estimation at maize and alpine meadow over the Heihe River Basin, China. International Journal of Applied Earth Observation and Geoinformation, 17, 94-101.

WWF Indonesia. 2014. Taman Nasional Sebangau. [Cited January,12 2014]. Available from URL : http://www.wwf.or.id/tentang_wwf/upaya_kami/forest_spesies/wherewework/sebangau/about sebangau/

Xiao, X., Zhang, Q., Braswell, B., Urbanski, S., Boles, S., Wofsy, S., Moore III, B., \& Ojima, D. (2004). Modeling gross primary production of temperate deciduous broadleaf forest using satellite images and climate data. Remote Sensing of Environment, 91(2), 256-270.

Yuan, W., Cai, W., Liu, S., Dong, W., Chen, J., Arain, M. A., ... \& Genesio, L. (2014). Vegetationspecific model parameters are not required for estimating gross primary production. Ecological modelling, 292, 1-10.

(C) 2018 by the authors; licensee Udayana University, Indonesia. This article is an open access article distributed under the terms and conditions of the Creative Commons Attribution (CC-BY) license (http://creativecommons.org/licenses/by/4.0/). 